\title{
Physical stature and biological living standards of girls and young women in the Netherlands, born between 1815 and 1865
}

\author{
Hans de Beer* \\ International Institute of Social History, Cruquiusweg 31, 1019 AT Amsterdam, The Netherlands
}

\begin{abstract}
This is the first study in Dutch anthropometric historiography that describes and analyzes the development of the biological standard of living of girls and young women from the perspective of female adult stature. It is shown that adult stature of women, imprisoned in the second half of the nineteenth century and born between 1815 and 1865 , slightly increased, approximately $1 \mathrm{~cm}$. From 1850 onwards stature of women born in the cities notably increased. Development of female adult stature was compared to that of male stature; both were quite similar. No circumstantial evidence was found that girls or young women were on a disadvantage with respect to nutrition and (medical) care.
\end{abstract}

(C) 2010 Elsevier Inc. All rights reserved.

Keywords: Physical stature; Netherlands; Gender; Nineteenth century; Nutrition; Infectious diseases; Discrimination; Mortality

\section{Nutrition, care, sex and biological living standards ${ }^{1}$}

In 19th century Belgium, it was not unusual for girls to be less well fed and cared for than boys, because girls' work brought in less money for the family than the work carried out by boys (Devos, 2000). In Devos' view, priority was given to supporting boys' working capacity. She gives no direct indications that girls were given less nutritious food. What she gives as evidence for the unequal apportionment of food within families is expressed in statements such as: 'It was mainly adult

\footnotetext{
* Tel.: +31 206685866 .

E-mail address: hdb@iisg.nl.

1 John Komlos introduced the concept of the "biological standard of living' to bring together under one term various aspects of the quality of life from a biological point of view; aspects such as general health, nutritional status as indicated by stature and/or weight, the frequency and duration of illnesses, exposure to pathogens or age-specific life expectancy (Komlos, 1993a, b).
}

men who were the first to benefit from progress [HdB: from the preferential consumption of food]' or '[...] mothers and daughters ate after fathers and sons. [...] The most important breadwinner had to be fed adequately and so was always given first choice of the available food. The best piece of meat was always reserved for the father' (Devos, 2000, p. 70-71). This merely illustrates that the breadwinner/father was given priority over the other members of the family. In writing about the Netherlands in the 19th century, Van Poppel (2000) maintains that it is unlikely that girls were not fed as well as boys. His view is that girls were exposed to infections more than boys, because it was usually they who looked after the sick. Moreover, girls were less well protected against certain infectious diseases such as diphtheria and smallpox. There were far fewer girls than boys in primary education and so they missed the vaccinations for these diseases that were compulsory for all primary-school children. It was also the task of schools, and still is, according to Van Poppel, to 
pass on knowledge about personal hygiene, so because fewer girls attended school than boys, they had less knowledge of this. Similarly, Van Poppel was unable to find any direct indications that girls had received less (medical) care than boys during that period.

Where now are the indications to be found that girls were disadvantaged at that time, compared with boys, with respect to nutrition and (medical) care? Both Devos and Van Poppel point to excess mortality among girls in the age range of 5-20 years. Devos observes that girls in this age category had a 5 to $25 \%$ greater chance of dying than their male counterparts: 'lung tuberculosis was the main cause of death and was the main reason for the difference in mortality rates between girls and boys'. This higher rate among girls was evident in both agrarian areas and urban regions (Devos, 2000, p. 63-66). Van Poppel identifies a similar pattern in the Netherlands: there was a higher mortality rate among girls between the ages of 5 and 19 years; the major cause of death being lung tuberculosis (Van Poppel, 2000, p. 119-122). A recent study conducted by Van Poppel, Schellekens, and Walhout (2009) revealed somewhat different results. Using data from the Historical Sample of the Netherlands (HSN) they did not observe excess mortality among girls in the age of 10 to 19 years, while the female-to-male mortality ratio was higher in the age of 1 to 9 years, though not statistically significant. According to Van Poppel, Schellekens and Walhout the absence of excess mortality of girls in the age of 10 to 19 years is due to the fact that the HSN is not nationally representative.

Van Poppel and Devos put the higher mortality rate down to two determinants, namely the greater exposure of girls to pathogens and/or lower physical resistance due to malnutrition/fewer vaccinations. However, several limitations are attached to tracing this higher mortality back to these two determinants. It cannot be dismissed that the higher mortality among girls due to lung tuberculosis - by far the most important cause of death - had more to do with biological differences or with interactions between environmental and biological factors, ${ }^{2}$ than with differences in the nutritional situations of both sexes; girls could perhaps have been more sensitive to the tuberculosis bacillus. ${ }^{3}$ Had girls been more underfed than boys, then

\footnotetext{
${ }^{2}$ A nice example illustrating interaction between environmental and biological factors comes from a study (Klein et al., 2008) showing that girls benefit more than boys from the protective effects of breast milk, but also that girls fed with baby formula are more likely to fall victim to a respiratory or lung infection than their siblings of opposite sex. The study population consisted of very low birth weight infants in the age of 30 weeks.

${ }^{3}$ There is not yet scientific consensus on sex-related differences in susceptibility to tuberculosis. See Holmes, Hausler and Nunn (1998).
}

one would have expected that the higher mortality would have resulted from various illnesses influenced by malnutrition. The Italian demographer Livi-Bacci (1991, table 7) has grouped infectious diseases according to whether they are 'certainly', 'possibly' or 'certainly not' related to malnutrition. In addition to tuberculosis, he lists measles, whooping cough, respiratory diseases, herpes, diarrhoea, and cholera as diseases that are certainly related to malnutrition. From Devos' overview of causes of death in the age group 7 to 21 years, it appears that girls die of measles, scarlet fever and whooping cough rather more frequently than do boys (1.4 compared with 1.1 per million), but that boys die of respiratory diseases more often than girls (6.1 compared with 5.1 per million) (Devos, 2000, table 4). The indications that the higher mortality rates among girls were linked to malnutrition appear, therefore, to be inconsistent. Secondly, whether or not girls were exposed to higher risks of infection, can also be questioned. On the surface, it sounds convincing that girls were more at risk because they cared for the sick, as argued by Van Poppel, however, the point should also be made, that because boys worked more outside the parental home, they came into contact with many more people, and so were exposed to higher risks of infection. Thirdly, one of the surprising findings in the study conducted by Van Poppel et al. (2009) is the excess mortality of girls in all ages (1-4, 5-9 and 10-19 years) of the elite, though not statistically significant. This finding seems to cast further doubt on the role of relative nutritional deprivation and/or increased exposure to pathogenic microorganisms in explaining excess mortality of girls.

The question of whether girls were less well fed and cared for can also be studied from a different angle, namely by investigating the nutritional status of girls and boys. A good indicator of nutritional status is stature. Within the bounds of genetic potential, the final height of a fully-grown adult reflects the net nutrition that the person received during the years prior to this. Net nutrition is the nutritional value of food intake minus the claims on that nutrition made by illness and (heavy) physical exertion (Steckel \& Floud, 1997, p. 1-16).

Several historians have linked the differences in stature developments between men and women with the discrimination of girls with respect to food and (medical) care. In England, the databases of detainees show that, the stature of females and males developed differently between 1790 and 1815. From this, Johnson and Nicholas (1997, p. 231) deduce that the extremely low family incomes would have made it necessary to divide the means of subsistence so that the family as a whole would gain maximum profit from it, and that this would have been coupled with a tendency to discriminate against girls. 
The reasoning behind this was that well-fed workers would earn more money than those that were under-fed, because they would be able to work longer, to take on heavier work, and would be more resistant to illnesses that would erode their capacity to carry out physical labour. With this argumentation in mind, parents divided up the scarce food in favour of the boys and men because, in a market economy, their working power was better paid (Johnson \& Nicholas, 1997, p. 213). Baten and Murray (2000, p. 368) describe how girls born in Bavaria in the period 1845-1849, during the 'potato crisis', were smaller as adults than the birth cohorts before them had been. In their research on stature trends in Europe during the first two thousand years, Koepke and Baten (2003, p. 79) observed that the more difficult the times, the more disadvantaged women became compared with men. This observation was based on the fact that, proportionally, the adult stature of women had decreased more than that their male counterparts.

Just as for differential mortality, when studying differential stature, one can raise the question of to what extent biological differences can modify the influence of environmental factors. Several researchers are of the opinion that boys are less resistant to malnutrition and its related diseases than girls (Eveleth, 1975; Gray \& Wolfe, 1980). So, should the supply of food improve, this would imply that boys' height would increase faster than that of girls. From this it also implies that the ratio of male to female stature would be larger in socially more affluent layers of society and that this ratio would increase proportionately in the course of time, the more nutrition improved and the less widespread the occurrence of infectious diseases (Brennan, McDonald \& Shlomowitz, 1997). Therefore, an increase in the ratio between male and female stature does not automatically indicate that girls were given less access to food and (medical) care. This appears to be confirmed by Brennan et al.'s research. Using a very large sample of Indian contract workers who were shipped from Calcutta and Madras to Fiji, Jamaica, Mauritius and Natal in the second half of the nineteenth century, they demonstrate that the ratio of the fully-grown statures of male and female adults increased proportionately depending on the status of the caste from which they had come. An inter-temporal comparison reveals the same phenomenon. In contrast, Moradi and Guntupalli (2009) report other results. Using a sample consisting of a large number of countries scattered over every continent, they researched the relationship between the calorie availability per head and the fully-grown stature of males and females during the second half of the twentieth century. This relationship appeared to be the same for both sexes. ${ }^{4}$ An analysis of stature data from Swedish populations from the 10th to the end of the 20th century also did not provide support for the assertion that male stature is more sensitive to environmental changes than female stature (Gustafsson, Werdelin, Tullberg \& Lindenfors, 2007). Taking the conflicting results into account, it cannot just be assumed that biological factors had no influence on changes in the ratio between male and female statures. ${ }^{5}$ In researching and interpreting differential developments in stature, it is advisable, in addition, to consider a 'conservative' point of departure for identifying discrimination against girls in relation to food and (medical care). That is to say: only a situation in which women's stature decreases, while men's stature remains at least stable, is evidence that girls were on a disadvantage.

In contrast to male stature, for the nineteenth century, there is very little information about the stature of women in the Netherlands. ${ }^{6}$ All that is available is one report from the De Vries Robbé Committee (de Vries Robbé, 18701872). This committee was set up in 1863 to give the Home Secretary insight into the possible effects of child labour on physical, ethical and spiritual development. The aim was 'to discover whether the situation of factory children in the Netherlands should be legislated or not'. In connection with this, the committee reported on the stature of orphan girls, school girls and female workers around 1865 .

The focus in this paper is on how the stature of girls born between 1815 and 1865 evolved, and the extent to which this trend mirrored or differed from the changes in the stature of boys, what factors influenced the fullygrown stature of both groups, and what is the relative significance of these factors. With an availability of food per head per day of around $2250 \mathrm{kcal}$, the food situation during this period was extremely precarious (de Beer, 2001, p. 39). Depending on the economic climate, the price of food could rise dramatically, and so the caloric availability would often have been less than this. ${ }^{7}$ In many families, it was often a question of dividing scarce

\footnotetext{
${ }^{4}$ In linear regression terms: women's height $=137.26+0.01 *$ kilocalories per day $\left(R^{2}=0.55\right)$. Men's height $=146.80+0.01 *$ kilocalories per day $\left(R^{2}=0.67\right)$ (Moradi \& Guntupalli, 2009, Fig. 1).

${ }^{5}$ For corresponding conclusion, see Harris (1998)

${ }^{6}$ For men's heights, see, among others, Drukker and Tassenaar, 1997; Tassenaar, 2000; de Beer, 2001; Maat, 2003; de Beer, 2004; Haines, 2004.

${ }^{7}$ For the relation between the economic situation and food prices, see: see Knotter and Muskee (1986), 'Conjunctuur en levensstandaard in Amsterdam 1815-1855. Een onderzoek op basis van plaatselijke accijnzen' ['The economic situation and living standards in Amsterdam 1815-1855. Research based on local excises'], Tijdschrift voor Sociale Geschiedenis [Journal of Social History] 12 (1986), 153-181.
} 
food. If the fact that girls were considered to be of lower economic value than boys was indeed a factor influencing this division of food, then the biological standard of living of girls must have been put under considerable pressure. We know from the data on the stature of keurlingen ${ }^{8}$ that the biological standard of living of boys was more or less stable during this period. This indicates that boys' biological living standards were also under pressure. ${ }^{9}$

\section{Annotations on the sources used}

The admission registers of prisons in the northern, central and southern parts of the country were used as source material. Most of the data relate to women and men who were detained in penitentiaries in the cities Leeuwarden, Utrecht and 's-Hertogenbosch. ${ }^{10}$ The detainees in the sample came from all part of the Netherlands, although very few of those in the sample had been born in the provinces of Zeeland, Limburg or Drenthe. For the male detainees, a systematic sample of 1 in 12 was taken. However, to avoid ending up with too small a number in the sample, data were collected about all the female

\footnotetext{
${ }^{8}$ Keurling is the Dutch word for boys or young men at that time who were tested for their suitability for military service.

${ }^{9}$ Here, I make use of data from Drukker and Tassenaar, 1997, Table 9A.1. For twenty-year-old keurlingen, they calculated a height of $165.9-166.1 \mathrm{~cm}$ (for those born between 1814 and 1816) and 166.4-166.9 cm (for those born between 1864 and 1866).

${ }^{10}$ Sources: Utrecht Municiple Archives - The archive of the Director of the prison on the Wolvenplein: inv.no. 283-315 (admission years 1861-1900); Tresoar, Archive of the House of Arrest, inv.no. 730, 737-739, 743-745 (admission years 1839-1842, 1863-1886), Archive of the House of Detention: inv.no. 867 (admission years 1891-1896), Archive of the auxiliary Convict Prison: inv.no. 933-935 (admission years 1888-1916), Archive of the House of Detention: inv.no. 815 (admission years 1863), inv.no. 866-876 (admission years 1888-1924), Archive of the House of Correction: inv.no. 864 (admission years 1879-1887), Archive of the House of Arrest inv.no. 746, 751 (admission years 1840, 1864-1885); State Archive of Noord-Holland, Archive of the House of Detention, Haarlem: inv.no. 135 (admission years 1873-1876), Archive of the House of Detention, Den Helder inv.no. 1-4 (admission years 18601869) inv.no. 7-8 (admission years 1880-1883), inv.no. 12-15 (admission years 1891-1901), House of Arrest, Alkmaar: inv.no. 148-150 (admission years 1883-1887), House of Detention, Alkmaar: inv.no. 180 (admission year 1883), Hoorn prisons: inv.no. 475-476 (admission years 1839-1844), 483-485 (admission years 1874-1886), 520-524 (admission years 1885-1888), Archive of the House of Detention, Purmerend: inv.no. 5 (admission years 18601861); Brabant Historical Information Centre, Archive of the prison for convicted offenders: inv.no. 306 (admission years 1862-1863), 310-330 (admission years 1863-1885), 425-427 (admission years 1890-1892), 450-451 (admission years 1898-1899), 482-486 (1908-1910).
}

detainees. ${ }^{11}$ With a few exceptions, the data came from prisoners detained in the second half of the nineteenth century. These data were used in order to make statements about the adult stature of birth cohorts of prisoners. This choice is based on the fact that the stature of fully-grown adults reflects the material circumstances in their initial years of life (Floud, Wachter \& Gregory, 1990, p. 227, 231-232, 242-243). For instance, the stature of a 40-yearold person, who was measured in 1880 , mainly reflects the material circumstances of cohorts of people who were born at the beginning of the 1840 s. In total, data were used from 7139 detainees (4514 men and 2625 women) in the age range 21 to 49 years, inclusive. These were checked to prevent them being counted twice. ${ }^{12}$ Data were also collected for children and adolescents (1007 girls and 1306 boys) who were also living in custody at that time. However, these will only be used here to gauge the reliability of the data on the stature of the adults.

The information in the registers is sometimes incompletely or inaccurately documented, in that decimetres and/or centimetres of the body height measured are missing here and there. The stature was hardly ever measured accurately to within a millimetre. Sometimes, information about whether a prisoner had completed primary school was also missing, or perhaps a signature or an indication of the person's occupation. Moreover, we could not find out how the detainees were measured. This task was probably allotted to the prison guard. ${ }^{13}$ Because of the need to get an exact description of the detainee, it can be assumed that, when measured, they would have been required to take off their shoes, leaving their socks on, but one cannot be sure. Because we were mainly interested in changes in stature, it is more important to know whether people had always been measured in the same way, than whether detainees were measured with their shoes on or off. If, from a certain moment, they were not measured in their shoes any more, then this would introduce a systematic measurement error into the data. From the next paragraph, it will appear that (systematic) measurement errors were, indeed, made. Despite this, we assume that the data on the stature of adult detainees is

\footnotetext{
${ }^{11}$ For every admission register, the data were used of the first male detainee to be registered, and then the thirteenth, etc. For female detainees, data were taken relating to every female whose data we came across in separate registers of female detainees, or in registers combining the data of both male and female detainees.

12 The registers mainly state whether it is a relapse or not. Furthermore, the family name, initials, and date of birth were checked to eliminate any 'administrative twins'.

${ }^{13}$ In the report of the Committee for Statistics for the year 1892, a warder in Roermond was praised for pioneering an instrument to measure the height of prisoners. Cited in Eggink, 1958, p. 112-113.
} 
reliable enough to make statements about changes in stature over the course of time.

Systematic measurement errors are evident in the data on women's stature taken from adult women who were detained in Utrecht from 1893 onwards. The average height of these women ranged from $160.0 \mathrm{~cm}$ in 1893-97 to $162.6 \mathrm{~cm}$ in $1898-1902$ to $165.7 \mathrm{~cm}$ in $1903-07$. Neither the increase of $6 \mathrm{~cm}$ in height within 10 years nor a height of $165.7 \mathrm{~cm}$ can be correct. ${ }^{14}$ One can only guess the reasons for these systematic measurement errors. The most likely ones are, for example, that a measuring rod was installed at the wrong height and that prisoners were measured with their shoes on. ${ }^{15}$ Measurement errors were probably also made in the periods 1863-67 (women, Leeuwarden), 1898-1902 (women, Leeuwarden; men, Utrecht) and $1878-82$ (women, Utrecht). ${ }^{16}$ However, it is important to note that measurement errors in these cases sometimes indicate an over-estimation of the height and sometimes an under-estimation. Apart from the measurement errors that were made in the data on the heights of women from 1893 onwards in the Utrecht sample, no indications were found that a measurement error had been made whereby the height of detainees had been systematically over or under estimated from a certain moment onwards. All data on stature that we consider not to be sufficiently reliable were not included in the analysis. This amounted to 1248 entries, or $15 \%$ of the total number of entries in the register. ${ }^{17}$

The reliability of data about stature can be checked in various ways. First we will concentrate on the data on the heights of children and adolescents. A number of patterns should be evident here, which apply in general to data about height from the nineteenth century to the present day:

- girls begin their growth spurt earlier than boys;

- girls reach their fully-grown adult height earlier than boys (van Wieringen, 1972, p. 75-76).

\footnotetext{
${ }^{14}$ In 1965 the (average) height of a 21 -year-old Dutch woman was $166.3 \mathrm{~cm}$. Women's height increased by about $1 \mathrm{~cm}$ a decade in the years that followed. See Fredriks et al., 1997, p. 1-13.

15 Oppers (1963, p. 48) reports of an unnamed institution that the carpenter, who attached the measuring rod against the wall, fixed it for convenience onto the skirting-board. This skirting-board was $5 \mathrm{~cm}$ in height. Consequently, the heights of groups of Dutch people measured and registered there over a two-year period were $5 \mathrm{~cm}$ smaller that their actual heights.

16 The criterium for identifying a suspected systematic measurement error is an increase or decrease in the average height of more than $2 \mathrm{~cm}$ within a period of 5 years. This is based on the observation that, in the collected material, 5-year averages usually differ less than $2 \mathrm{~cm}$ from each other.

${ }^{17}$ Data were collected from a total of $7139+1248=8387$ adult detainees.
}

Table 1

The height (in $\mathrm{cm}$ ) of children, adolescents and adults (born in the period $1815-1865$ and aged 11 to 39 years) who were detained.

\begin{tabular}{llllll}
\hline Age group & Men & & & \multicolumn{2}{l}{ Women } \\
\cline { 2 - 3 } \cline { 5 - 6 } & Average & $\begin{array}{l}\text { 95\% confidence } \\
\text { interval }\end{array}$ & & Average & $\begin{array}{l}\text { 95\% confidence } \\
\text { interval }\end{array}$ \\
\hline $11-12$ & 130.4 & $128.2-132.7$ & & 128.4 & $122.3-134.5$ \\
$13-14$ & 136.6 & $134.4-138.7$ & & 140.7 & $137.6-143.7$ \\
$15-16$ & 150.9 & $149.1-152.8$ & & 150.5 & $148.5-152.4$ \\
$17-18$ & 159.4 & $158.0-160.8$ & & 153.6 & $152.7-154.5$ \\
$19-20$ & 165.0 & $164.3-165.8$ & & 156.4 & $155.6-157.3$ \\
$21-29$ & 167.9 & $167.6-168.2$ & & 156.2 & $155.8-156.6$ \\
$30-39$ & 168.2 & $167.9-168.6$ & & 157.2 & $156.8-157.6$ \\
\hline
\end{tabular}

Source: Database of detainees.

Are these patterns also evident in our data on children and adolescents? The heights given in Table 1 give a clear indication of this pattern. A comparison of the heights of children of both sexes in the age ranges $11-$ 12 and 13-14 years clearly shows that the girls began their growth spurt earlier than boys. The girls also appear to have reached their fully-grown adult height at around their nineteenth year, while, for the boys, it was after their twentieth year. Moreover, the data show a constant increase in height with age until the fullygrown adult height was reached.

The De Vries Robbé Committee, mentioned earlier, had the height and weight of a large number of Dutch school children measured during the period 1863-1867. To what extent do these data show similarities with our data about children and adolescents? The relevant information is included in Table 2 .

The body heights in Table 2 give the impression that the girls and boys in custody were smaller than the children of the same age measured for the research commissioned by the De Vries Robbé Committee. This suggests that the data on the stature of detainees is not so reliable. However, that is not the case. As we shall see later, most of the prisoners came from the lower social classes; it is to be expected then that, due to poorer nutrition and less care, they would be smaller than the school children who had a more varied social background.

The reliability of our data on stature can also be tested by comparing the stature of adult male detainees with height information gained from military statistics. Between 1850 and 1861, the De Vries Robbé Committee published information on the number of young men drafted into the armed forces ${ }^{18}$ who were smaller than $157 \mathrm{~cm}$ : these conscripts were almost 19 years old when

\footnotetext{
${ }^{18}$ Keurlingen, who had passed the suitability test for military service, were then conscripted into the armed forces by lottery.
} 
Table 2

Height (in cm) of school children and orphans and children who were detained (calendar period 1863-1867).

\begin{tabular}{|c|c|c|c|c|c|c|}
\hline \multirow[t]{3}{*}{ Age group } & \multicolumn{2}{|c|}{ School children and orphans } & \multicolumn{4}{|c|}{ Detained children } \\
\hline & \multirow{2}{*}{$\frac{\text { Boys }}{\text { Average }}$} & \multirow{2}{*}{$\frac{\text { Girls }}{\text { Average }}$} & \multicolumn{2}{|l|}{ Boys } & \multicolumn{2}{|l|}{ Girls } \\
\hline & & & Average & $\begin{array}{l}95 \% \text { confidence } \\
\text { interval }\end{array}$ & Average & $\begin{array}{l}95 \% \text { confidence } \\
\text { interval }\end{array}$ \\
\hline $11-12$ & 131.9 & 129.8 & 129.5 & $126.8-132.1$ & 123.5 & $115.3-131.7$ \\
\hline $13-14$ & 140.7 & 139.7 & 134.8 & $131.9-137.7$ & 141.0 & $137.9-144.0$ \\
\hline $15-16$ & 153.0 & 151.9 & 150.1 & $147.5-152.6$ & 147.2 & $144.8-149.7$ \\
\hline
\end{tabular}

Source: De Vries Robbé, Appendix K; Database of detainees.

they were measured. ${ }^{19}$ The Committee did this for all municipalities in the provinces of Noord-Brabant, Gelderland, Noord-Holland and Zuid-Holland, Utrecht and Overijssel. From this, the percentage of conscripts from each municipality who were taller than $157 \mathrm{~cm}$ can be deduced. One can assume in municipalities where a higher percentage of conscripts were taller than $157 \mathrm{~cm}$, that the (adult) male detainees from the same municipality would also be taller. ${ }^{20}$ Although the conscripts would have continued to grow after their nineteenth year, especially those who were smaller, for the average conscript the following rule of thumb would still have applied: those who were smaller at the age of nineteen would also have been smaller at the age of twenty-one or twenty-two when they reached their fully-grown adult stature, even though the differences in height may have become significantly smaller. ${ }^{21}$ So, if the data on stature of adult male detainees is reliable, a fair correlation

\footnotetext{
${ }^{19}$ De Vries Robbé, $1870-1872$, p. $314-452$ and State D.

${ }^{20}$ Elsewhere in the text, it is shown that, in general, detainees come from the lower social strata. Conscripts were taken from all sections of the population. This doesn't necessarily weaken the comparison, as long as the social composition of the municipalities from which the detainees and conscripts came (see footnote 20) are more or less comparable.

${ }^{21}$ Elsewhere (De Beer, 2001, p. 176-177), I have devised a number of formulas for comparing the height of a 19-year-old conscript with his fully-grown adult height. In these formulas, a linear connection is assumed between (1) the percentage of conscripts who were smaller than $157 \mathrm{~cm}$ and the height of the average conscript at the age of 19 years, and (2) the height of the average 19-year-old conscript and the extent of their growth to fully-grown adult height. To illustrate this, I include the following figures. If the average height of the conscripts was $157.5 \mathrm{~cm}$ when they were 19 years old, then one can expect their fully-grown adult height to be $165.6 \mathrm{~cm}$. However, should conscripts of the same age have an average height of $163.4 \mathrm{~cm}$, then one can expect their fully-grown height to be $168.1 \mathrm{~cm}$. A difference of $8 \mathrm{~cm}$ at 19 years of age will be reduced to a difference of $2.5 \mathrm{~cm}$ in their final adult heights. So there is evidence of catching-up on growth, but this is insufficient to compensate completely for the difference in height. Because the estimated fullygrown adult height is a linear transformation of the percentage of conscripts smaller than $157 \mathrm{~cm}$, and the extent of the growth, the correlation coefficient given in the text should also apply, if we had used the estimated fully-grown adult height of the conscripts, instead of the percentage of conscripts smaller than $157 \mathrm{~cm}$.
}

between these heights and heights of conscripts would be expected. The average height of male prisoners from a number of cities has been calculated and linked to the percentage of conscripts who were taller than $157 \mathrm{~cm}^{22}$ The correlation coefficient is $0.507(N=23 ; p=0.013)$, which indicates a moderate correlation.

Above, we have given three ways of investigating the reliability of the data on the stature of detainees. The outcome of this inventarisation is, in our opinion, that these data on stature are sufficiently reliable to research any trends that may have taken place at that time.

The discussion and analysis of the stature of adult detainees remains restricted to the age group 21 up to, and including, 49 years. There are two reasons for this. It can be said with certainty that men did not reach their fullygrown adult height before the age of 21 years (see Table 1). ${ }^{23}$ The second reason is that the fully-grown adult height does not remain a constant for the rest of a person's life, but decreases the older the person becomes. The 'shrinkage' begins at an age of between 30 and 40 years and by about the age of 50 years has increased to as much as 0.5 and almost $1.0 \mathrm{~cm}$ for men and women, respectively (Sorkin, Muller \& Andres, 1999). These statistics apply to individuals living in the second half of the twentieth century. There are no indications that the 'shrinkage' in the nineteenth century was any different.

\section{Social and anthropometric characteristics of adult detainees}

Various sorts of data about the prisoners are included in Table 3. From this information, we can see that far fewer of the female detainees could read and write than

\footnotetext{
${ }^{22}$ It concerns the following municipalities: Alkmaar, Amersfoort, Amsterdam, Arnhem, Breda, Delft, Den Bosch, 's-Gravenhage, Den Helder, Deventer, Dordrecht, Gouda, Haarlem, Kampen, Leiden, Nijmegen, Rotterdam, Schiedam, Tilburg, Utrecht, Zaandam, Zutphen, Zwolle. The discussion is restricted to these municipalities because they had populations of over 10,000 inhabitants in 1859, and these, as mentioned later in the text, are over-represented in the sample.

${ }^{23}$ See also De Beer, 2001, passim.
} 
Table 3

Composition of the sample of detainees per birth cohort according to age group, literacy and place of birth (percentages and totals).

\begin{tabular}{|c|c|c|c|c|}
\hline & \multicolumn{4}{|c|}{ Male detainees born in } \\
\hline & $1815-29$ & $1830-39$ & $1840-49$ & $1850-65$ \\
\hline $21-29$ years & 7.5 & 38.9 & 57.6 & 56.4 \\
\hline 30-39 years & 32.8 & 44.3 & 26.2 & 33.4 \\
\hline $40-49$ years & 59.8 & 16.8 & 16.2 & 10.2 \\
\hline Literates & 68.6 & 68.9 & 71.1 & 80.0 \\
\hline $\begin{array}{l}\text { Born in municipalities } \\
\text { with } 10,000 \text { or } \\
\text { more inhabitants }\end{array}$ & 45.8 & 41.3 & 34.4 & 32.9 \\
\hline \multirow[t]{3}{*}{ Total } & 1004 & 1184 & 1106 & 1220 \\
\hline & \multicolumn{4}{|c|}{ Female detainees born in } \\
\hline & $1815-29$ & $1830-39$ & $1840-49$ & $1850-65$ \\
\hline $21-29$ years & 2.8 & 22.6 & 51.0 & 55.4 \\
\hline 30-39 years & 25.6 & 52.5 & 27.9 & 32.8 \\
\hline $40-49$ years & 71.5 & 24.9 & 21.1 & 11.9 \\
\hline Literates & 33.5 & 44.5 & 50.1 & 58.8 \\
\hline $\begin{array}{l}\text { Born in municipalities } \\
\text { with } 10,000 \text { or } \\
\text { more inhabitants }\end{array}$ & 39.1 & 45.3 & 36.6 & 27.3 \\
\hline Total & 425 & 634 & 782 & 784 \\
\hline
\end{tabular}

Sources: Database of detainees; Uitkomsten der 4de tienjarige volkstelling in het Koningrijk der Nederlanden op den 31sten December 1859 [Results of the 4th 10-yearly population census in the Kingdom of the Netherlands held on 31 December 1859].

their male counterparts; they were also much less literate than, for example, the brides in the Netherlands who signed their marriage certificates (Boonstra, 1993). Around 1850 only approximately $65 \%$ of the brides were able to sign their marriage certificates, but by around 1890 the percentage had increased to approximately $90 \%$. The same trend can be seen in the prison population, where the percentage of literate female detainees also increased. Male prisoners were less literate than Dutch bridegrooms. Around 1850, approximately $82 \%$ of the bridegrooms were able to sign their marriage certificates. By around 1890, this percentage had increased to approximately $95 \%$. An increase in literacy can also be seen among male detainees.

Many of the adult women (42\%) had, in their own words, no occupation. Twenty percent of the women worked as cleaner, maid or housekeeper and $16 \%$ as worker or day-worker. Only $7 \%$ of the adult male detainees had stated that they had no occupation. The most frequently named occupations were those of labourer, farmhand or day-worker $(33 \%)$, porter $(6 \%)$ and vender $(4 \%)$. Farmers, those with an intellectual occupation or employees are hardly ever encountered in these prison populations. Giele and Van Oenen (1976) estimated that, around $1850,30 \%$ of the male population were labourers. In the sample of detainees used here, this is $44 \%{ }^{24}$ According to Giele and Van Oenen, around $1850,27 \%$ of the male population were farmers. In our sample of detainees, only $2 \%$ were farmers.

Most of the male detainees appeared to have come from the lowest social classes. One would expect that a cross-section of this group would be smaller in stature than average. This is confirmed by the information presented in Table 4 in which the social status of prisoners is used as an indicator of the social status of the family in which the detainee grew up. ${ }^{25}$ More highly educated professionals and managers were taller on average than $170 \mathrm{~cm}$, and farmers were also a part of this group. ${ }^{26}$ Surprisingly, no differences in stature are evident between skilled, experienced and unskilled workers. Without doubt, one of the reasons for this is that also within these social strata there were differences in stature. This is illustrated very well by the difference in height - of more than $3 \mathrm{~cm}$ - between a shoemaker and a carpenter (Table 4). This difference probably reflected more than just a difference in social status. It is well known that some occupations attract people of a stronger physique, and other occupations people who are physically weaker. It is said of shoemakers that their work '[...] is both sedentary and physically undemanding. [...]. Small, weak or physically handicapped boys were habitually put to this trade' (Hobsbawm \& Scott, 1984, p. 113). One would be more likely to say the opposite about carpenters.

With a few exceptions, the women in the sample hardly showed any variation in height. This is partly because there were no higher educated professionals or managers in the sample (see Table 4). Farmers' wives

\footnotetext{
${ }^{24}$ The category of workers includes (land )workers, farmhands, porters, polder and dike-workers, fishermen, sailors, boathands, workmen, factory workers, and applies to the period before 1849 .

${ }^{25}$ The following procedure was adopted to determine the social status of an occupation. The occupations were coded using the Historical International Standard Coding of Occupation (van Leeuwen, Maas \& Miles, 2002). The codes used can be found in the document: hiscostructure.rtf. These codes were then recoded using the document: hisco_hisclass12a_@.inc. An unspecified occupation, such as 'worker' was coded again as 'unskilled worker' or as 'unskilled farmhand' according to whether the birthplace of the detainee was in an urban or rural area. The above-mentioned documents can be found on http://historyofwork.iisg.nl/(12 June 2007). The social status of the detainee's occupation is used as an indicator of the social status of the family in which this person grew up. It was assumed, thereby, that there was very little occupational mobility from one generation to the next at that time. Only the occupations practised by at least 100 detainees in our samples are included in Table 4.

${ }^{26}$ The estimates of the heights of managers and professionals with a higher education are not very accurate. This can be seen from the wide confidence intervals.
} 
Table 4

The height (in $\mathrm{cm}$ ) of male and female detainees (born between 1815 and 1865) by social status and by various occupations.

\begin{tabular}{|c|c|c|c|c|c|c|}
\hline & \multicolumn{3}{|l|}{ Women } & \multicolumn{3}{|l|}{ Men } \\
\hline & $\begin{array}{l}\text { Number } \\
\text { (percentage) }\end{array}$ & Average & $\begin{array}{l}95 \% \text { confidence } \\
\text { interval }\end{array}$ & $\begin{array}{l}\text { Number } \\
\text { (percentage) }\end{array}$ & Average & $\begin{array}{l}95 \% \text { confidence } \\
\text { interval }\end{array}$ \\
\hline Higher management & - & - & - & $6(0.1)$ & 170.2 & $164.6-175.8$ \\
\hline Higher educated professional & - & - & - & $13(0.3)$ & 170.8 & $165.7-175.8$ \\
\hline Lower management & - & - & - & $21(0.5)$ & 170.3 & $167.3-173.3$ \\
\hline $\begin{array}{l}\text { Lower educated professionals, } \\
\text { administrative and sales occupations }\end{array}$ & $169(6.4)$ & 156.6 & $155.6-157.5$ & $307(6.8)$ & 168.3 & $167.5-169.1$ \\
\hline - Merchant (m/f) & & 155.9 & $154.6-157.2$ & & 168.0 & $167.0-168.9$ \\
\hline $\begin{array}{l}\text { Lower administrative and } \\
\text { sales occupations }\end{array}$ & $12(0.5)$ & 161.7 & $155.9-167.4$ & $32(0.7)$ & 165.3 & $161.6-169.0$ \\
\hline Foreman/housekeeper & $13(0.5)$ & 158.8 & $154.9-162.6$ & - & - & - \\
\hline Skilled worker (m/f) & $6(0.2)$ & 155.2 & $150.2-160.1$ & $778(17.2)$ & 167.4 & $166.9-167.9$ \\
\hline - Carpenter & & - & - & & 169.4 & $168.2-170.6$ \\
\hline - Shoemaker & & - & - & & 165.9 & $164.7-167.0$ \\
\hline Farmers/farmer's wives & $6(0.2)$ & 165.2 & $158.8-171.5$ & $134(3.0)$ & 168.7 & $167.7-169.8$ \\
\hline Experienced workers (m/f) & $526(20.0)$ & 156.4 & $155.8-156.9$ & $649(14.4)$ & 167.0 & $166.4-167.5$ \\
\hline - Seamstress & & 156.3 & $154.9-157.6$ & & - & - \\
\hline - Servant (f) & & 156.1 & $155.2-156.9$ & & - & - \\
\hline Experienced farmhand & & & & $108(2.4)$ & 168.9 & $167.6-170.2$ \\
\hline Unskilled labourers (m/f) & $276(10.5)$ & 157.4 & $156.6-158.2$ & $835(18.5)$ & 167.5 & $167.0-168.0$ \\
\hline - Porter & & & & & 168.4 & $167.5-169.2$ \\
\hline - Cleaner (f) & & 157.6 & $156.8-158.5$ & & - & - \\
\hline Unskilled farm labourers (m/f) & $368(14.0)$ & 157.2 & $156.6-157.8$ & $1159(25.7)$ & 168.6 & $168.2-168.9$ \\
\hline No (classified) occupation & $1248(47.5)$ & 156.7 & $156.3-157.0$ & $472(10.5)$ & 167.6 & $166.9-168.3$ \\
\hline & $2625(100.0)$ & 156.8 & $156.6-157.1$ & $4514(100.0)$ & 167.8 & $167.6-168.0$ \\
\hline
\end{tabular}

Source: Database of detainees.

and women who worked in lower administrative and retail trades appeared to be rather tall.

The average height of female and male prisoners was 156.8 and $167.8 \mathrm{~cm}$, respectively. Therefore, compared with prisoners in Bavaria, England or Ireland, they were rather tall. They were between 0.5 and $0.7 \mathrm{~cm}$ taller than detainees in Bavaria and from 1.5 to $2.5 \mathrm{~cm}$ taller than detainees with an English or Irish background (Baten \& Murray, 2000, table 4; Johnson \& Nicholas, 1997, fig. 6.11). The stature of male detainees, in so far as they came from urban environments, can also be compared with the stature of men who, in the nineteenth century, were active as civic guards in a number of towns and cities in the Netherlands. Male detainees from urban environments appear to have been $2 \mathrm{~cm}$ smaller. ${ }^{27}$ This is a rather small difference if we take into account that these guards were certainly not drawn from the lowest layers of society and it is perhaps indicative of a limited degree of social inequality within the working classes.

The female and male detainees came often from the towns, although this percentage diminished the later in

\footnotetext{
${ }^{27}$ See de Beer, 2004, Fig. 3. The cities are: Groningen, Assen, Goes, Roermond, Nijmegen, Leiden, and Rotterdam.
}

the nineteenth century that these cohorts were born. ${ }^{28}$ On average, $40 \%$ of the males and $33 \%$ of the females who were detained came from towns (see Table 3). According to the census of 1859 , approximately $30 \%$ of the inhabitants lived in towns with a population of over $10,000{ }^{29}$ Women who grew up in towns were $0.7 \mathrm{~cm}$ (156.4 compared with $157.1 \mathrm{~cm}$; $95 \%$ confidence interval of difference in height: $0.2-1.2 \mathrm{~cm}$ ) shorter than women elsewhere. ${ }^{30}$ The same applies for men, except that there is a greater difference in height, namely $1.6 \mathrm{~cm}$ (166.8 compared with $168.4 \mathrm{~cm}$; 95\%

\footnotetext{
${ }^{28}$ In calculating the relevant percentages in Table 3, only Leeuwarden is included in the province of Friesland.

${ }^{29}$ Uitkomsten der 4de tienjarige volkstelling in het Koningrijk der Nederlanden op den 31sten December 1859. When comparing both percentages, it must be borne in mind that what is being compared are the places of residence (of the national population) and the birth places (of the detainees). Due to the increasing movement of population from rural areas to the towns and cities during the second half of the nineteenth century, the difference between both of these percentages would have been greater.

${ }^{30}$ A $t$ test was used to test the difference between avarages. Levene's test of the assumption of the equal variance of both distributions was insignificant $(F=3.56 ; p=0.059)$.
} 
confidence interval of difference in height: $1.2-$ $2.0 \mathrm{~cm}) .{ }^{31}$ In summary, we can conclude that a significant proportion of the women and men in the prison population came from lower social strata and had grown up in towns.

Many of those detained were sitting out prison sentences for theft, vagrancy or for begging. If we go by the number of women and men who had to appear before a district court for one of these offences, then the number of accused amounted to 0.35 women and 1.12 men per 1000 of the population. ${ }^{32}$ Offences such as theft or begging are sensitive to economic fluctuation: in times of crises, the number of these sorts of offences will tend to increase and in times of (relative) prosperity they will tend to decrease. Between 1850 and approximately 1890, the number of people who were prosecuted for one of the offences named above, decreased. This was not only indicative of an improving economic situation, but also of the occurrence of selection bias. ${ }^{33}$ Now, this need not be an immediate problem, because we are mainly interested in comparing female and male stature. The occurrence of selection bias due to a sex-specific reaction to shifts in economic fluctuations would be a bigger problem. However, it appears that men and women did not react differently in this respect. In the years that more men were accused of theft, vagrancy or begging, the pattern was the same for women, and vice versa. ${ }^{34}$

From Table 3 it could be inferred that both women and men were jailed at an ever younger age. However, that was not the case; the phenomenon arises from using a sample that is organised according to the year of admittance into the penitentiary from approximately the middle of the nineteenth century onwards.

\footnotetext{
${ }^{31}$ A $t$ test was used to test the difference between avarages. Levene's test of the assumption of the equal variance of both distributions was significant $(F=12.73 ; p=0.000)$. This is taken into account when determining the lower and upper limits of the confidence interval.

${ }^{32}$ We base this on figures given in the Geregtelijke (Gerechtelijke) statistiek van het Koningrijk der Nederlanden voor de jaren $1855 \mathrm{t} / \mathrm{m}$ 1860, 1861, 1863, 1864 t/m 1866, 1868 t/m 1881, 1890, 1892, 1894 [(Judicial) statistics of the Kingdom of the Netherlands for the years 1855 up to and including 1860,1861, 1863, 1864 up to and including 1881, $1890,1892,1894]$. Theft includes (1) simple theft and (2) aggravated theft.

${ }^{33}$ With respect to selection bias, we focus on a situation where a sample is not representative of the entire population; in this case, the lower social strata. The drop in the number (of charges for) offences such as theft and begging, can also be indicative of less efficient action on the part of the police and the courts.

${ }^{34}$ The Spearman correlation coefficient and the annual fluctuations in the number per 1000 of the population of men charged by the district courts for theft, vagrancy or begging (including boys under 16 years of age) and women (including girls under the age of 19 years) is 0.833 $(p<0.001)$. This refers to the years listed in footnote 30 .
}

All in all, we can assume that shifts in the relationship between the statures of male and female prisoners had more to do with the interaction between biological and environmental factors than that it was an outcome of selection bias.

\section{Determinants of how individual adult heights in women and men developed}

Which factors influence the development of the individual heights of women and men, and which factors have more, and which have less influence? This is the core question that will be dealt with in this section. Let us begin by sketching developments in women's stature between 1815 and 1865 (see Fig. 1). Three phases can be observed. The first phase is characterised by a period lasting up to about 1830, during which women's height remained constant. Between around 1830 and 1841, women became shorter, on average, by approximately $1 \mathrm{~cm}$, but from 1841 onwards, they began to get steadily taller. Men's average height followed the same pattern, and the changing points of around 1830 and 1841 are identical. Nevertheless, there are a number of differences: during the first phase, men grew taller, while the height of women remained unchanged; while in the third phase, women became taller at a faster rate than the men. If we look at development in height from a longer-term perspective, there is no reason to assume that, as far as nutrition and care are concerned, girls were worse off than boys. Overall, the increase in height was more or less the same.

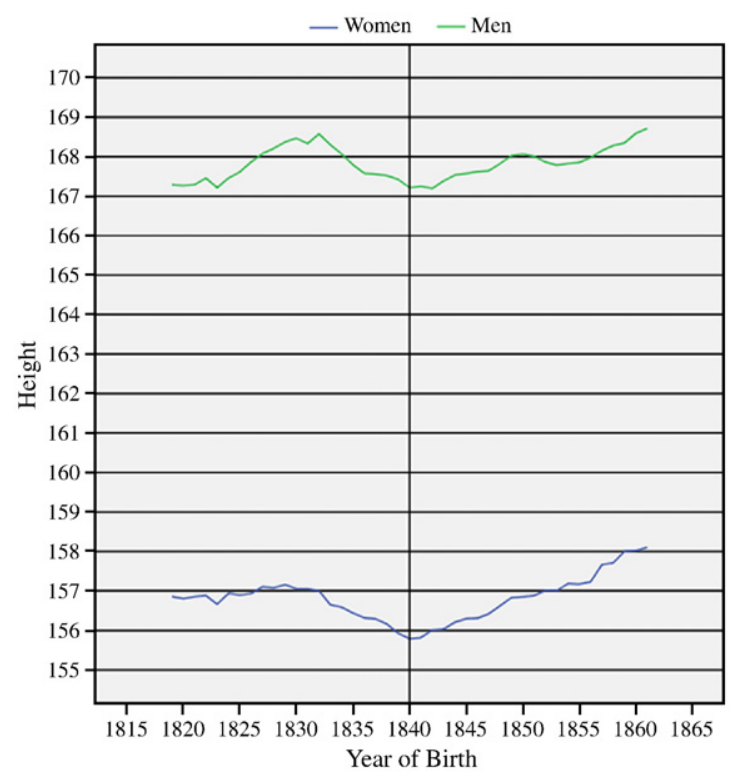

Fig. 1. Trends in height (9-yearly moving averages, in $\mathrm{cm}$ ) of women and men born between 1815 and 1865. Source: Database of detainees 
The same conclusion can be drawn if we choose the 'conservative' points of departure as given in the introduction, namely that the decrease in height of women - while the height of men at least remained constant - is an indication that girls were discriminated against with respect to food and (medical) care. When, from around 1830 onwards, the adult height of females began to decrease, the same happened for the men, and to the same degree: by more than $1 \mathrm{~cm}$. Nevertheless, the question can still be posed as to why the way women's height evolved was initially unfavourable, but later favourable. An attempt will be made to gain more insight into this, using a regression analysis to explore the effect of different determinants of individual stature.

One of the determinants of individual stature has already been given, namely an urban environment. Girls and boys who grew up in towns appear to be less tall than those who grew up in rural areas. It is not difficult to guess why an urban environment had a negative effect on growth in the nineteenth century. It was more difficult in the towns than in the countryside to find cheap food. In towns and cities, with their large concentrations of people, with houses built close together and bad drinking water, the risks of catching infectious diseases were much greater than in rural areas. Those who survived these conditions, had a reasonable chance of suffering a definitive retardation in their growth, and in that sense were marked for life. ${ }^{35}$

From military statistics, it is known that, in the nineteenth century, there were differences in height from province to province among keurlingen (de Beer, 2001, chapters III-IV). We can now pose the question of whether this was purely the result of differing rates of provincial urbanisation or whether there were other influencing factors. To answer this question, we calculated the average height of female and male detainees in every province, excluding all towns and cities with populations of more than 10,000 inhabitants. This reveals differences between the various provinces: women and men from rural areas in the southern provinces (NoordBrabant, Limburg and Zeeland) were smaller than elsewhere; however, men and women from rural areas in the remaining provinces were almost equally tall. The extent of these differences will be discussed later in the article. ${ }^{36}$ In any case, different rates of urbanisation in the

\footnotetext{
${ }^{35}$ For more information on the higher mortality rates in urban areas, see van Poppel, 1985.

36 The ANOVA test is used to investigate whether there are general height differences between people from different provinces (excluding the towns and cities). For men: $F=6.005, p=0.000$; for women: $F=7.230, p=0.000$. The Scheffé test is used to investigate which provinces appear to give deviating heights for men and women.
}

various provinces largely explain the existence of height differences in people from one province to another.

Another determinant of individual height is family income. After all, with a higher income, the children can be fed and cared for better. As far as care is concerned, one can think, for example, of buying warm clothing, of easyto-wash cotton underwear, and making sure that it is regularly cleaned, or using soap to improve personal hygiene. ${ }^{37}$ Due to the lack of information about family incomes, we have to resort to using an indicator. There are good reasons for using literacy as an indicator for this. Boonstra (1993, p. 51) in his study of literacy in Eindhoven and the surrounding municipalities in the nineteenth century pointed out that learning to read and write in the nineteenth century was expensive. It required: 'not only school fees, money for books or clothes, but also money due to loss of income from work' ${ }^{38}$ Children of parents with a higher income had more chance of being able to go to school. Literacy is not only a socioeconomic, but also a socio-cultural indicator; we have already cited Van Poppel (2000) who thought that schools were instrumental in advancing personal hygiene. In so far as literacy - in relation to family incomes - indicates better nutrition and care, and - because of schools indicates better personal hygiene at a young age, a positive relation can be expected with height in adulthood. That such a relation exists is confirmed by the following figures. Female detainees who could read and write had an average height of $157.3 \mathrm{~cm}$ (95\% confidence interval: $157.0-157.7 \mathrm{~cm}$ ); female detainees who were illiterate were $1 \mathrm{~cm}$ smaller, on average: $156.3 \mathrm{~cm}$ (95\% confidence interval: $156.0-156.7 \mathrm{~cm}$ ). Male detainees who could read and write were also $1 \mathrm{~cm}$ taller than their fellow prisoners, who were illiterate: $168.2 \mathrm{~cm}(95 \%$ confidence interval: $167.9-168.4 \mathrm{~cm})$ versus $167.1 \mathrm{~cm}(95 \%$ confidence interval: $166.7-167.5 \mathrm{~cm}$ ).

For the purpose of a multivariate regression analysis of the height of individuals, three determinants have so far been identified: growing up in a town, growing up in one of the southern provinces and illiteracy. To determine the relative significance of these factors, it is necessary to incorporate a few other variables in a regression model. It was pointed out earlier that people become smaller as they grow older. To correct for this in a regression model, we make use of a dummy variable

\footnotetext{
37 According to Landes (1993, p. 161) the use of cotton underwear was a substantial advance as far as hygiene was concerned. The woollen underwear that was worn prior to this caused skin irritation, and regularly scratching the irritated areas in turn led to transferring pathogenic microbes from the hands and from food into the stomach and intestinal canal.

${ }^{38}$ See also van Zanden (1991, p. 41-42).
} 
Table 5

Regression model for determinants of adult height (expressed as a standard deviation score).

\begin{tabular}{|c|c|c|c|c|c|c|}
\hline \multirow[t]{2}{*}{ Variable } & \multicolumn{3}{|l|}{ Men } & \multicolumn{3}{|l|}{ Women } \\
\hline & Coefficient $^{\mathrm{a}}$ & $\begin{array}{l}\text { Standardised } \\
\text { coefficient }\end{array}$ & $T$ value & Coefficient $^{\mathrm{a}}$ & $\begin{array}{l}\text { Standardised } \\
\text { coefficient }\end{array}$ & $T$ value \\
\hline Constant & $\begin{array}{l}-2.148 * * * \\
(-2.245 ;-2.052)\end{array}$ & - & 43.661 & $\begin{array}{l}-2.050 * * * \\
(-2.179 ;-0.921)\end{array}$ & & 31.205 \\
\hline Literate $^{\mathrm{b}}$ & $\begin{array}{l}0.181 * * * \\
(0.114 ; 0.248)\end{array}$ & 0.082 & 5.324 & $\begin{array}{l}0.125 * * * \\
(0.048 ; 0.201)\end{array}$ & 0.064 & 3.187 \\
\hline Born in towns ${ }^{b}$ & $\begin{array}{l}-0.383 * * * \\
(-0.456 ;-0.309)\end{array}$ & -0.187 & -10.146 & $\begin{array}{l}-0.279 * * * \\
(-0.375 ;-0.184)\end{array}$ & -0.137 & -5.754 \\
\hline Born in $1815-29$ & Ref. cat & - & & Ref. cat & - & \\
\hline Born in $1830-39^{\mathrm{b}}$ & $\begin{array}{l}-0.017 \\
(-0.108 ; 0.074)\end{array}$ & -0.008 & -0.375 & $\begin{array}{l}-0.048 \\
(-0.176 ; 0.081)\end{array}$ & -0.021 & -0.725 \\
\hline Born in $1840-49^{b}$ & $\begin{array}{l}-0.119 * \\
(-0.213 ;-0.026)\end{array}$ & -0.052 & -2.500 & $\begin{array}{l}-0.089 \\
(-0.215 ; 0.038)\end{array}$ & -0.041 & -1.375 \\
\hline Born in $1850-65^{\mathrm{b}}$ & $\begin{array}{l}-0.107 \\
(-0.216 ; 0.002)\end{array}$ & -0.047 & -1.916 & $\begin{array}{l}-0.007 \\
(-0.150 ; 0.136)\end{array}$ & -0.003 & -0.097 \\
\hline Age $40-49^{\mathrm{b}}$ & $\begin{array}{l}-0.114 * * \\
(-0.192 ;-0.035)\end{array}$ & -0.049 & -2.837 & $\begin{array}{l}0.100 * \\
(0.005 ; 0.194)\end{array}$ & 0.045 & 2.068 \\
\hline $\begin{array}{l}\text { Born in the provinces of } \\
\text { Noord-Brabant, Limburg } \\
\text { or Zeeland }\end{array}$ & $\begin{array}{l}-0.186 * * * \\
(-0.269 ;-0.103)\end{array}$ & -0.072 & -4.400 & $\begin{array}{l}-0.330 * * * \\
(-0.441 ;-0.219)\end{array}$ & -0.121 & -5.846 \\
\hline Farmer's wife ${ }^{\mathrm{b}}$ & - & - & - & $\begin{array}{l}1.246 * * \\
(0.475 ; 2.018)\end{array}$ & 0.062 & 3.167 \\
\hline Experienced worker $^{\mathrm{b}}$ & $\begin{array}{l}-0.103 * \\
(-0.188 ;-0.019)\end{array}$ & -0.036 & -2.391 & - & - & - \\
\hline Born in towns * Born in $1850-65^{\mathrm{c}}$ & $\begin{array}{l}0.336 * * * \\
(0.194 ; 0.478)\end{array}$ & 0.094 & 5.354 & $\begin{array}{l}0.404 * * * \\
(0.224 ; 0.583)\end{array}$ & 0.112 & 4.414 \\
\hline$N$ & 4260 & & & 2549 & & \\
\hline$F(d f=9)$ & 17.876 & & & 12.288 & & \\
\hline$R_{\text {adj }}^{2}$ & 0.034 & & & 0.038 & & \\
\hline Durbin-Watson statistic & 1.855 & & & 1.937 & & \\
\hline
\end{tabular}

Key: ${ }^{\mathrm{a}} 95 \%$ confidence intervals are given between parentheses; ${ }^{\mathrm{b}}(1=$ yes, $0=$ no $)$; ${ }^{\mathrm{c}}$ interaction effect; ${ }^{\mathrm{d}}$ due to the small number of detainees from Limburg and Zeeland, these provinces have been combined with Noord-Brabant. Levels of significance: $* p<0.05 ; * * p<0.01 ; * * * p<0.001$.

Source: Database of detainees.

'aged 40-49' that has a value of 1 if someone belongs to this age group. Another variable is related to the fact that some categories of social status appear to produce a deviant height (see Table 4). ANOVA results confirm that the heights of all status categories are not equal; by means of a Bonferroni test we have assessed which categories differed statistically significant from each other. ${ }^{39}$ There is some evidence that living in an urban environment had fewer disadvantages from the middle of the century onwards. According to Van Zanden and Van Riel (2000, p. 158, p. 167) the trends in real wages for industrial and agricultural workers between 1850 and 1865 were different: the wages of agricultural workers stagnated, while there was a steady improvement in the wages for industrial workers. So we introduce an interaction term, born in towns*born in

\footnotetext{
${ }^{39}$ ANOVA test: $F=3.856, p=0.000$ (men); $F=3.289, p=0.000$ (women)
}

1850-65. To make proper comparisons, the heights of men and women must be standardised for biological differences in growth potential (Steckel, 2009). We standardise male and female heights by converting them to $z$-scores of modern height standards. The $z$-score converts heights into units of standard deviation by taking the deviation of the individual's height from the mean and dividing by the standard deviation for every sex category. Data from the fourth Dutch growth study (1997) were used as modern height standards; mean final height at age 21 for boys and girls amounted to $184.0 \mathrm{~cm}$ (S.D. 7.1) and $170.6 \mathrm{~cm}$ (S.D. 6.5), respectively (Fredriks et al., 2000).

The results of the regression are given in Table 5.

The variance $\left(R^{2}\right)$ explained by the variables that predict the heights of females and males is very small, namely about $3-4 \%$. The reason for this is that individual height is strongly determined by hereditary factors. In accordance with expectation, men in the age group of 40 
49 years were smaller than younger men. Surprisingly enough, for women in this age group, that was not the case; they were taller. Perhaps this is a chance finding, because, as appears from an inspection of the data, only those women who were born after 1850 were taller than the younger women. The results of the regression analysis confirm that girls, and boys alike, who grew up in towns and cities, were on average smaller as adults. What is remarkable, however, is that this effect was less strong for women than for men. ${ }^{40}$ As was noted earlier, the food situation in the towns was, in general, less favourable than in the countryside. Had the lower economic value of girls been a reason for discriminating them in favour of the boys, when apportioning scarce supplies of food, then this is more likely to have happened in the urban areas. However, this does not appear to have taken place. The results of the regression analysis confirm that both women and men alike, who were born in the southern provinces were smaller than their counterparts elsewhere, although this provincial difference was clearly more pronounced for women. Thus adult women in the southern provinces were $2.1 \mathrm{~cm}$ shorter than women elsewhere; for men, the difference was $1.3 \mathrm{~cm}$ (see Table 5). ${ }^{41}$ This could indicate discrimination of girls in these provinces. ${ }^{42}$ In the period $1850-1865$ it seems that girls, in particular, and boys too, who were born in towns became approximately $2.5 \mathrm{~cm}$ taller on average. ${ }^{43}$ This indicates that stature developed differently in urban areas to that of people growing up in the countryside. Fig. 2 gives an overview of the changes in general height of women and men born in towns or in the countryside. Urban women began with a growth deprivation of about $3 \mathrm{~cm}$, by around 1850 their height is equal to that of women from the countryside, and by 1865 they were ahead with respect to height by $1 \mathrm{~cm}$. In contrast to this, the height of women from rural areas remained on average unchanged, and the same applied to men who were born and grew up in rural areas, while the changes in stature of both men and women from urban areas followed a parallel pattern. In addition, the regression analysis indicates that the three most important determinants of women's height were: growing up in

\footnotetext{
${ }^{40}$ The beta coefficient - the standardised regression coefficient - is -0.137 for women and -0.187 for men. Strictly speaking it is not correct to compare the regression coefficients of both regression models because not all variables are similar. However rerunning the regression analysis while omitting the dissimilar variable (Experienced worker and Farmer's wife) produces the same results.

$412.1 \mathrm{~cm}$ is the product of the regression coefficient in Table 5 $(-0.330)$ and the standard deviation of the reference group (6.5); $1.3 \mathrm{~cm}$ is likewise the product of -0.186 and 7.1 .

${ }^{42}$ The beta coefficient is -0.121 for women and -0.072 for men.

${ }^{43}$ Calculation is the same as is explained in footnote 42 .
}

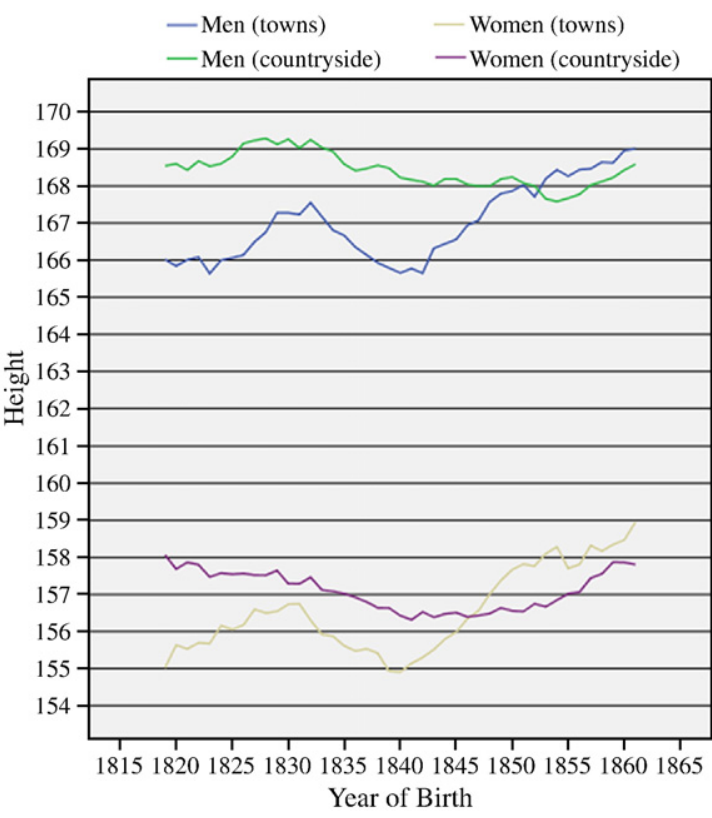

Fig. 2. Trends in height (9-yearly moving averages, in $\mathrm{cm}$ ) of women and men born between 1815 and 1865, in towns and in the countryside. Source: Database of detainees.

towns, growing up in the southern provinces, and growing up in an urban area from 1850 onwards. These were combined with literacy also the most important determinants of men's heights. ${ }^{44}$

The relatively favourable development in height in the towns from around the middle of the nineteenth century onwards (compare Fig. 2 and Table 5) probably reflects living standards in towns developed more favourably than in the coutryside as was suggested by Van Zanden and Van Riel (2000).

In many aspects, the results of the foregoing analysis agree with what Johnson and Nicholas (1997) and also Baten and Murray (2000) have found. Johnson and Nicholas came to the conclusion that women who were born in the English countryside between 1815 and approximately 1840 were, in general, taller than women originating from the English urban areas. According to them, this indicated, among other things, the poorer living conditions and the greater exposure to diseases in the urban areas. In the period 1840-1849 men and women became shorter in general, both in the towns and in the countryside (Johnson \& Nicholas, 1997, table 6.1, fig 6.9, p. 225 , p. 228, p231). Baten and Murray (2000, Table 4, p. 367-368) find that men, born in a middle-sized town between 1810 and 1889 , were $2 \mathrm{~cm}$ shorter than those

\footnotetext{
${ }^{44}$ The most important determinants were identified from the size of the standardised regression coefficients.
} 
who were born in rural areas. They point, as do Johnson and Nicholas to a relatively unfavourable environment with respect to infectious diseases in the towns. It is remarkable, however, that these urban inconveniences did not manifest themselves in more restricted growth in the women who grew up in middle-sized towns; only women from Munich were shorter - by about $1.2 \mathrm{~cm}$ - than rural women. Another difference between the data from Bavaria and the Netherlands is that they show that the growth in stature of women from Bavaria during the potato crises there of the 'hungry forties' was curtailed, and that this did not happen with the men. The Dutch data, therefore, are less similar to the data from Bavaria, and more similar to the ones from England.

One theme has not been dealt with so far, namely the possibility of the fully-grown adult stature being influenced by a selective effect caused by early death. According to Alter $(2004$, p. 266) high mortality rates can lead to an effect whereby '[...] short people will be less likely to survive to adulthood. Consequently, those who become adults will be relatively taller. This implies that an increase in the proportion surviving to adulthood (i.e., a decrease in mortality) can lead to a decrease in average height. In other words, if growing taller leads to longer life, cohorts with longer lives may be shorter as adults. If the selective effect of mortality on adult height is large, improvements in mortality may be confused with a worsening standard of living'. This implies that if girls in certain age groups suffer higher rates of mortality than boys, then the more robust and taller girls who survive, will be those whose height is a less sensitive factor with respect to environmental influences. Therefore, very little significance should be attached to the almost similar developments in height, in the long term, between women and men (see Fig. 1). The issue that then arises is: what trends do the death statistics for girls and boys reveal?

Apart from the years 1827 and 1828, national mortality data, specified by age and sex, are only available from the middle of the nineteenth century onwards (see Fig. 3) (Tabeau, Willekens, \& van Poppel, 1994; van der Bie \& Smits, 2001). From this graph, it appears that deaths among girls under 20 years of age between 1850 and 1865, follow grosso modo the same pattern as that for the boys. ${ }^{45}$ It is unlikely that, during this period, a selective effect with respect to body height

\footnotetext{
$\overline{45}$ Correlation coefficient is $0.63(p=0.009, N=16)$. If we leave out the mortality data in the year 1860 then the correlation coefficient is $0.98(p=0.000, N=15)$.
}

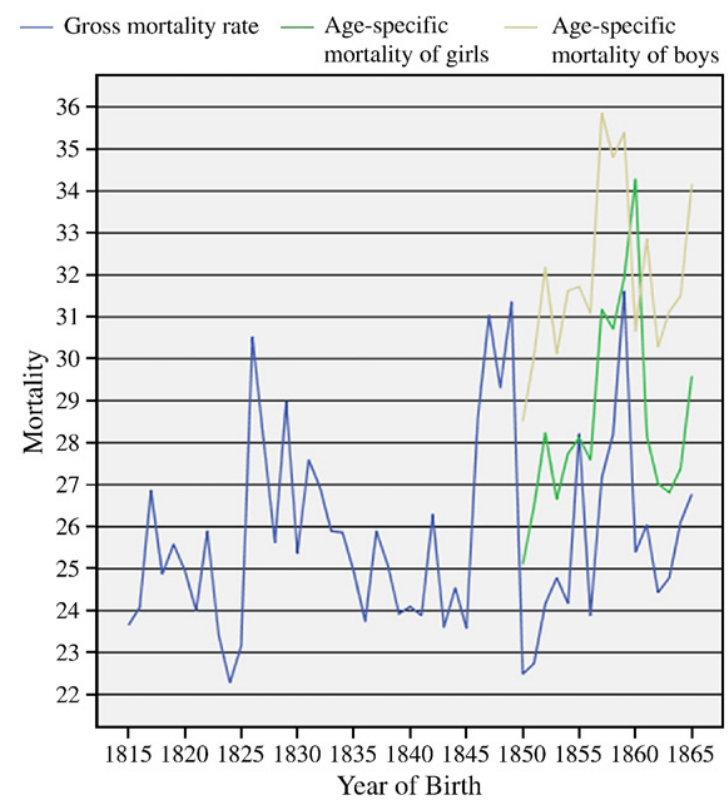

Fig. 3. The gross mortality figures (no. of deaths per 1000 of the population) and mortality specified by sex in the age group $0-19$ years (no. of deaths per 1000 in the given age group), 1815-1865. Source: Tabeau et al. (1994); van der Bie and Smits (2001); Human Mortality Database, 2007.

would have occurred. It is difficult to make judgements about the period before 1850 , since the availability of sex-specific mortality data is restricted to two years (1827/28). Van Poppel et al. (2009) point to the fact that excess mortality in girls in the years 1827 and 1828 only rarely occurred, and became manifest from the middle of the nineteenth century. So, if we assume that excess mortality of girls only rarely occurred in the first decades of the nineteenth century, excess mortality must have originated in the thirties and forties. This implies that we cannot exclude a selective effect of early death on adult stature of those female prisoners who were born between $1827 / 1828$ and 1850 . On the other hand, development of male and female stature is so similar, also in the thirties and forties, that a selective effect, if there was any, was insignificant.

\section{Conclusion and discussion}

The aim of this study has been to contribute to research on the trends in the biological living standards of girls and young women in the nineteenth century. The results of this study indicate some improvement from the end of the 1840 s onwards. Biological living standards rose, particularly in the urban areas, and mostly among those who were literate. This is not surprising, because during the first decade, it was precisely in the towns where biological 
living standards left much to be desired. The extent of the improvement in the biological living standards of girls and young women is comparable with that of boys and young men.

In contrast to the studies of Devos and Van Poppel, this study gives no indications that girls in the Netherlands, apart from those who grew up in the southern provinces, were worse off, with regard to nutrition and care, than boys. The indicators for this are that (1) the increase in the fully-grown height of men and women during a period of 50 years was more or less the same; (2) the negative effects on adult stature of growing up in towns - where poor biological living standards over a long period were conducive to discrimination against girls - were no worse for women than for men; and (3) that, when in the 1840 s the biological living standard worsened, and women became smaller, their decrease in height was proportionally the same as that for the men at that time. The fact that the data on height give other indications than differences in mortality rates raises the question of which indications are the more reliable, especially as assumed causes of higher mortality rates among girls, or of a possible unfavourable difference between the average heights of females and males, are basically the same: a relatively worse nutritional status due to poorer nutritional intake and higher claims on that nutritional intake because of exposure to, or less protection from, pathogenic microbes.

In the first place, we note that restrictions may be attached to both indicators. In the introduction, in connection with the higher mortality rates of girls, the remark was made that it is not very likely that malnutrition among girls would result in an increased risk of dying from lung tuberculosis, with no, or hardly any, increased risk of dying from another infectious disease to which people with malnutrition are known to be susceptible. Henry $(1989$, p. 196) is of the opinion that women are more susceptible to tuberculosis than men, and that this might be linked to hormonal changes that take place during puberty. As far as height is concerned, as indicated in the introduction, there might be biological differences between girls and boys: according to some researchers (Eveleth, 1975; Gray \& Wolfe, 1980), girls may be able to cope better with malnutrition.

A second point is that the indicators relate to age groups that differ in part from each other. The fully-grown adult height that is used here as an indicator of nutritional status is, by definition, related to the age cohort that has at least survived the first 21 years of life, and whose cumulative net-nutrition during those years will be reflected in the end-height to which they have grown as adults. The higher mortality rates for girls apply only to the age group of 5-19 years. In other words, the food and care in the initial years of life, and during the years just before reaching the maximum growth in height as an adult, is not reflected in this indicator.

Based on the above, one could say then, that girls and boys, who were in the first 21 years of their lives during the period 1815-1865, received, on average, a similar level of nutrition and care, or alternatively, that girls, who had been deprived in their early youth with regard to food and care, recovered again in later youth.

This study has a number of limitations. There is no guarantee that selective effects on the trends in stature of men and women, due to differing developments in mortality patterns will not have had an influence on the data. The male and female detainees whose heights have been analysed came mostly from the lowest layers of the population and from the towns. This implies that these results cannot automatically be applied to the whole population.

\section{References}

Alter, G. (2004). Height, frailty, and the standard of living: Modelling the effects of diet and disease on declining mortality and increasing height. Population Studies, 58(3), 265-279.

Baten, J., \& Murray, J. E. (2000). Heights of men and women in 19thCentury Bavaria: Economic, nutritional, and disease influences. Explorations in Economic History, 37(4), 351-369.

Boonstra, O. W. A. (1993). 'De waardij van eene vroege opleiding'. Een onderzoek naar de implicaties van het alfabetisme op het leven van inwoners van Eindhoven en omliggende gemeenten, 1800-1920 (The value of early education. An investigation into the implications of literacy on the lives of the residents of Eindhoven and neighbouring municipalities, 1800-1920). Landbouwuniversiteit en Uitgeverij Verloren: Wageningen.

Brennan, L., McDonald, J., \& Shlomowitz, R. (1997). Sex differences in Indian height at home and abroad. Man in India, 77(2\&3), 105-118.

de Beer, H. (2001). Voeding, gezondheid en arbeid in Nederland tijdens de negentiende eeuw. Een bijdrage tot de antropometrische geschiedschrijving (Nutrition, health and work in the Netherlands during the nineteenth century. A contribution to anthropometric historiography). Amsterdam: Aksant.

de Beer, H. (2004). Observations on the history of Dutch physical stature from the late-Middle Ages to the present. Economics \& Human Biology, 2(1), 45-55.

de Vries Robbé, A. A. C. (1870-72). Rapport der commissie belast met het onderzoek naar den toestand der kinderen in fabrieken arbeidende [Report of the Committee responsible for investigating the situation of children who work in factories].'s. Gravenhage: Van Weelden en Mingelen.

Devos, I. (2000). Te jong om te sterven. De levenskansen van meisjes in België omstreeks 1900 [Too young to die. The chances of survival for girls in Belgium around 1900]. Tijdschrift voor Sociale Geschiedenis. Journal of Social History, 26(1), 55-75.

Drukker, J. W., \& Tassenaar, V. (1997). Paradoxes of modernization and material well-being in the Netherlands during the nineteenth century. In R. H. Steckel \& R. Floud (Eds.), Health and welfare 
during industrialization (pp. 331-377). Chicago: Chicago University Press.

Eggink, J. W. (1958). De geschiedenis van het Nederlandse gevangeniswezen [The history of the prison system in the Netherlands]. Assen: Van Gorcum.

Eveleth, P. B. (1975). Differences between ethnic groups in sex dimorphism of adult height. Annals of Human Biology, 2(1), 35-39.

Floud, R., Wachter, K., \& Gregory, A. (1990). Height, health and history. Nutritional status in the United Kingdom. 1750-198. Cambridge: Cambridge University Press.

Fredriks, A. M., van Buuren, S., Burgmeijer, R. J. F., et al. (1997). Nederlandse groeidiagrammen in historisch perspectief. [Dutch growth diagrams in historical perspective]. In J. M. Wit (Ed.), De vierde landelijke groeistudie (1997), Presentatie nieuwe groeidiagrammen, 1-13 [The 4th national investigation into growth (1997). Presenting new growth diagrams]. Leiden: Rijksuniversiteit Leiden.

Fredriks, A. M., van Buuren, S., Burgmeijer, R. J., Meulmeester, J. F., Beuker, R. J., Brugman, E., Roede, M. J., Verloove-Vanhorick, S. P., \& Wit, J. M. (2000). Continuing positive secular growth change in The Netherlands 1955-1997. Pediatric Research, 47(3), 316-323.

Geregtelijke (Gerechtelijke) statistiek van het Koningrijk der Nederlanden (1850-1897) [Judicial statistics of the Kingdom of the Netherlands]. 's-Gravenhage.

Giele, J., \& van Oenen, G. J. (1976). Theorie en praktijk van het onderzoek naar de sociale structuur [Theory and practice of researching social structure], Tijdschrift voor Sociale Geschiedenis. Journal of Social History, 5(1976), 167-186.

Gray, J. P., \& Wolfe, L. D. (1980). Height and sex dimorphism of stature among human societies. American Journal of Physical Anthropology, 53(3), 441-456.

Gustafsson, A., Werdelin, L., Tullberg, B. S., \& Lindenfors, P. (2007). Stature and sexual stature dimorphism in Sweden, from the 10th to the end of the 20th century. American Journal of Human Biology, 19(6), 861-870.

Haines, M. R. (2004). Growing incomes, shrinking people - Can economic development be hazardous for your health? Historical evidence for the United States, England and the Netherlands in the nineteenth century. Social Science History, 28(2), 249-270.

Harris, B. (1998). Gender, height and mortality in nineteenth and twentieth-century Britain: Some preliminary reflections. In J. Komlos \& J. Baten (Eds.), The biological standard of living in comparative perspective (pp. 413-448). Stuttgart: Franz Steiner 1998.

Henry, L. (1989). Men's and women's mortality in the past. Population: An English selection, 44(1), 177-201.

Historical International Standard Coding of Occupation (2007). Available: http://historyofwork.iisg.nl/ (21 June 2007).

Hobsbawm, E. J., \& Scott, J. W. (1984). Political shoemaker. In E. J. Hobsbawm (Ed.), Worlds of Labour: Further Studies in the History of Labour. London: Weidenfeld \& Nicolson.

Holmes, C. B., Hausler, H., \& Nunn, P. (1998). A review of sex differences in the epidemiology of tuberculosis. The International Journal of Tuberculosis and Lung Disease, 2(2), 96-104.

Human Mortality Database. University of California, Berkeley (USA), and Max Planck Institute for Demographic Research (Germany). Available at www.mortality.org (21 June 2007).

Johnson, P., \& Nicholas, S. (1997). Health and welfare of women in the United Kingdom, 1785-1920. In R. H. Steckel \& R. Floud (Eds.), Health and welfare during industrialization. Chicago: Chicago University Press.

Klein, M. I., Bergel, E., Gibbons, L., Coviello, S., Bauer, G., Benitez, A., Serra, M. E., Delgado, M. F., Melendi, G. A., Rodríguez, S.,
Kleeberger, S. R., \& Polack, F. P. (2008). Differential gender response to respiratory infections and to the protective effect of breast milk in preterm infants. Pediatrics, 121(6), e1510-e1516.

Knotter, A., \& Muskee, H. (1986). Conjunctuur en levensstandaard in Amsterdam 1815-1855. Een onderzoek op basis van plaatselijke accijnzen [The economic situation and living standards in Amsterdam 1815-1855. Research based on local excises], Tijdschrift voor Sociale Geschiedenis. Journal of Social History, 12, 153-181.

Koepke, N., \& Baten, J. (2003). The biological standard of living in Europe during the last two millennia. European Review of Economic History, 9(1), 61-95.

Komlos, John (1993). The secular trend in the biological standard of living in the United Kingdom, 1730-1860. Economic History Review, 46(1), 115-144.

Komlos, John (1993). Further thoughts on the nutritional status of the British population. Economic History Review, 46(2), 364-365.

Landes, D. S. (1993). The fable of the dead horse; or the industrial revolution revisited. In J. Mokyr (Ed.), The British industrial revolution. An economic perspective (pp. 128-159). Boulder: Westview Press.

Livi-Bacci, Massimo (1991). Population and nutrition. An essay on European demographic history. Cambridge: Cambridge University Press.

Maat, G. (2003). Male stature. A parameter of health and wealth in The Low Countries, 50-1997 AD. In W. H. Metz (Ed.), Wealth, health and human remains in archaeology (pp. 57-88). Amsterdam.

Moradi, A., \& Guntupalli, A. M. (2009). What does gender dimorphism in stature tell us about discrimination in rural India, 1930-1975. In Manoranjan Pal et al. (Ed.), Gender and Discrimination: Health, Nutritional Status, and Role of Women in India (forthcoming). Paper presented at the 2nd Economics and Human Biology Conference (Munich, 2-6 June 2004).

Oppers, V. M. (1963). Analyse van de acceleratie van de menselijke lengtegroei door bepaling van het tijdstip der groeifasen [An analysis of the acceleration in human growth in height, determined from the time of the growth phases]. Amsterdam: Universiteit van Amsterdam.

Sorkin, J. D., Muller, D. C., \& Andres, R. (1999). Longitudinal change in height of men and women: Implications for the interpretation of the body mass index. The Baltimore longitudinal study of aging. American Journal of Epidemiology, 150(9), 969-977.

Steckel, R. H. (2009). Heights and human welfare: Recent developments and new directions. Explorations in Economic History, 46, $1-23$.

Steckel, R. H., \& Floud, R. (1997). Introduction. In R. H. Steckel \& R. Floud (Eds.), Health and welfare during industrialization (pp. 1-16). Chicago: Chicago University Press.

Tabeau, E., van Poppel, F., \& Willekens, F. (1994). Mortality in the Netherlands: The data base. NIDI report $n r$. 36. Den Haag: NIDI.

Tassenaar, V. (2000). Het verloren Arcadia. De biologische levensstandaard in Drenthe, 1815-1860 [ The Lost Arcadia. The biological living standard in Drenthe, 1815-1860]. Capelle a/d IJssel: Labyrint Publication.

Uitkomsten der 4de tienjarige volkstelling in het Koningrijk der Nederlanden op den 31 sten December 1859 (1863-1864) [Outcomes of the 4th 10-yearly census in the Kingdom of the Netherlands on 31 December 1859]. 's-Gravenhage: Van Weelden en Mingelen.

van der Bie, R. J., \& Smits, J. P. (2001). Tweehonderd jaar statistiek in tijdreeksen 1800-1999 [Two hundred years of statistics and time series, 1800-1999]. Amsterdam: Uitgeverij Stichting Beheer IISG.

van Leeuwen, M. H. D., Maas, I., \& Miles, A. (2002). HISCO: Historical International Standard Classification of Occupations. Leuven: Leuven University Press. 
van Poppel, F. W. A. (1985). Stad en platteland in demografisch perspectief [Towns and the countryside in demographic perspective]. Holland, 17(2), 161-180.

Van Poppel, F. (2000). Long-term trends in relative health differences between men and women. European Journal of Obstetrics \& Gynecology and Reproductive Biology, 93(2), 119-122.

Van Poppel, F., Schellekens, J., \& Walhout, E. (2009). Oversterfte van jonge meisjes in Nederland in de negentiende en eerste helft twintigste eeuw [Excess mortality of girls in the Netherlands in the nineteenth and first half of the twentieth centuries], Tijdschrift voor Sociale en Economische Geschiedenis. Journal of Social and Economic History, 4, 37-69.

van Wieringen, J. C. (1972). Seculaire groeiverschuiving. Lengte en gewicht surveys 1964-1966 in Nederland in historisch perspectief
[Trends in Secular Growth. Height and weight surveys 1964-1966 in the Netherlands, in historical perspective]. Leiden: Netherlands Institute for Preventive Medicine TNO.

van Zanden, J. L. (1991). "Den zedelijken en materiëlen toestand der arbeidende bevolking ten platten lande". Een reeks rapporten uit 1851 ("The ethical and material circumstances of working inhabitants of the countryside". A series of reports from 1851). Groningen: Nederlands Agronomisch-Historisch Instituut.

van Zanden, J. L., \& van Riel, A. (2000). Nederland 1780-1914. Staat, instituties en economische ontwikkeling (The Netherlands 1780-1914. State, institutions and economic development). Amsterdam: Balans. 